\title{
KANS GRASS - A PROMISING RAW MATERIAL FOR PAPERMAKING
}

\author{
ARVIND KUMAR SHARMA, RAVI GODIYAL and BIPIN PRAKASH THAPLIYAL \\ *Central Pulp and Paper Research Institute, Himmat Nagar, \\ Saharanpur (UP), India \\ × Corresponding author: A. K. Sharma, arvind17sharma@yahoo.com
}

Received May 16, 2018

Kans grass (Saccharum spontaneum) is a perennial grass that grows in India. In northern India, particularly in states of the country like Bengal, Bihar and Orissa, it is cultivated along with major crops. The fiber extracted from Kans grass is strong and flexible. It is broadly used for the manufacture of cordage, ropes, mats and baskets. Considering its wide availability, in this work, Kans grass is evaluated with regard to its papermaking potential, by investigating its fiber morphology, proximate chemical analysis. The optimization of soda pulping, as well as conventional and ECF bleaching, was performed to produce papermaking bleached pulp. Kans grass was found to have the average fiber length of $1.4 \mathrm{~mm}$ and width of $15.4 \mu \mathrm{m}$. Also, it presented the following chemical composition: $69.2 \%$ holocellulose content, 22.4\% Klason lignin, 6.76\% ash content and 32.3\% N/10 alkali solubility, which proved beneficial from the papermaking perspective. The optimized soda pulping at $165{ }^{\circ} \mathrm{C}, 16 \%$ alkali charge $(\mathrm{NaOH})$ and bath ratio of $1: 5$ allowed obtaining unbleached pulp with 17.7 kappa number, pulp yield of $45.5 \%$ and viscosity of $627 \mathrm{~cm}^{3} / \mathrm{g}$. Pulp with 85\% (ISO) brightness could be achieved by using $\mathrm{CEpH}_{1} \mathrm{H}_{2}$ and $\mathrm{DEpD}$ bleaching sequences. It was observed that the physical strength properties of $\mathrm{CEpH}_{1} \mathrm{H}_{2}$ and DEpD bleached pulps were comparable with those of other widely used non-wood materials for papermaking. These results revealed that Kans grass could be an important source of raw material for producing bleachable grade pulp under the processes and parameters established in this work.

Keywords: Kans grass, pulping, papermaking

\section{INTRODUCTION}

Forest based wood raw materials and bamboo grass have come to stir concerns because of increasing costs, fast depletion of forest resources and its impact on the ecological balance. ${ }^{1}$ A good option is to use fast-growing wood species to augment the wood supply for the development of pulp and paper industry due to their costeffectiveness and their superior fiber yield. Meanwhile, on a global level, the pulp and paper industry has turned to the use of alternative nonwood fibers for the production of various grades of paper. At present, $20-25 \%$ of the pulp and paper production in India uses various agricultural residues, such as bagasse, straw and grasses. The estimated total availability of non-woody fibrous plants is 2300 million tonnes, out of which about $65 \%$ are straws. ${ }^{2}$ In order to solve the depleting supply of wood raw material, the use of unconventional raw materials is one of the best options for the Indian pulp and paper industry.

Bamboo and mixed hardwood are the fibrous raw materials that are traditionally used for making pulp and paper in India by the large paper mills. The small and medium sized mills depend on agro-based raw materials, such as bagasse, straws and grasses, for the production of pulp and paper. Bagasse is a by-product of the sugar industry, which results after the extraction of sugar from sugar cane. Presently, only 7-10\% of surplus bagasse is available for the pulp and paper production, the rest is used for co-generation of steam in the sugar industry. To resolve the raw material demand, the Indian pulp and paper industry is searching for new alterative annual fibrous plants, in addition to bamboo and hardwood. The objective of the present study was to find out the potential of Kans grass, an annual plant found in India, as a fibrous raw material for Indian pulp and paper industry. It is apparent that the grass family can be an important alternative of non-wood raw material.

Kans grass (Saccharum spontaneum) is a potential non-food source of ligno-cellulose, which can be cultivated on barren land, without competing with food crops. Kans grass mainly grows in the hilly region of northern India and extends up to the equatorial regions of Java. Kans grass is a hard and scraggy plant, normally 
disliked by cattle. Cattle generally use fodder when other grasses are not available. This plant biomass is accessible throughout the year, without requiring much farming effort and with low demand of water supply.

Kans grass is a perennial grass, often empty in the center, with the diameter in the range from 5 to $15 \mathrm{~mm}$, often rooting at the nodes, with usually long internodes and nodes always thicker than the internodes. Leaves are long, linear and narrow in shape, the leaf module or ratio of breadth to length varying from $1: 24$ to $1: 300$ or more, in different species. Leaves are 1-2 meter long and 3 $\mathrm{cm}$ broad.

As Kans grass consists of adequate amounts of total carbohydrates (cellulose and hemicelluloses), in the range of $64-67 \%$, it has been considered to be utilized for bioethanol production. $^{3}$ Also, the upper leaf sheaths of the flowering culms of Kans grass have been evaluated for fiber extraction and for the production of pulp. Some studies indicated the possibility to use Kans grass as raw pulping material for paper-making purposes. Specifically, Kans grass has been found suitable for the production of semi-bleachable grade, writing, printing and grease-proof grade papers. ${ }^{4-5}$

In view of the above, in the present study, the proximate chemical analysis of Kans grass was carried out, and it was pulped and bleached for the production of bleachable grade pulp/paper. The characteristics of the extracted cellulosic fiber were studied by morphological analysis and other techniques.

\section{EXPERIMENTAL}

\section{Preparation of raw material}

Kans grass biomass was collected from the premises of Central Pulp and Paper Research Institute (CPPRI), Saharanpur, Uttar Pradesh, India. Kans Grass was cut into small pieces $(0.5-1.0 \mathrm{~cm})$. After cutting, it was kept in a polythene bag to attain uniform moisture content. The moisture content of the material was determined in duplicate, before the commencement of the experiments. Green Kans grass in the field is shown in Figure 1.

\section{Chemical proximate analysis of Kans grass}

Proximate chemical analysis of Kans grass was carried out in the CPPRI laboratory. First, the Kans grass was ground to powder using a Wiley Mill (Thomas Scientific), passed through a 40 mesh and collected in a polythene bag. The chemical proximate analysis, comprising the determination of ash (TAPPI T $244 \mathrm{~cm}-99$ ); cold and hot water solubility (TAPPI T
$207 \mathrm{~cm}-99) ; 0.1 \mathrm{~N} \mathrm{NaOH}$ solubility (TAPPI T 212 om02); alcohol benzene solubility (TAPPI T $204 \mathrm{~cm}-97$ ); acid insoluble lignin (TAPPI T 222 om-02) and alpha-, beta- and gamma-cellulose (TAPPI T $203 \mathrm{~cm}-09$ ) were determined. Holocellulose was analyzed by the chlorite-acetic acid method. Pentosan content was determined using ultraviolet spectroscopy.

\section{Morphology of Kans grass pulp}

Detailed anatomical characteristics, such as fiber length, fiber width, curl and kink index, were evaluated using a Hi-Resolution Fiber Quality Analyser (Optest Equipment Inc., model: LDA 2002). All the other characteristics, such as cell wall thickness, lumen diameter, length of parenchyma, length of vessel etc., were determined using a projection microscope.

\section{Optimization of soda pulping of Kans grass}

Pulping experiments were carried out by the soda process, using different doses of cooking chemicals, i.e. 14,16 and $18 \% \mathrm{NaOH}$, in order to optimize the demand of cooking chemicals, to obtain bleachable grade pulps of kappa number around 15-17.

Soda pulping experiments were performed in a laboratory series digester consisting of six digestion units, each with the capacity of 2.5 liters. The digester rotates in an electrically heated polyethylene glycol bath. The cooking temperature and time were monitored by a Digital Temperature Controlled (DTC) system. At the end of the cooking time, the digestion units were removed and quenched in the water tank to cool down and the cooked mass from each unit was taken for washing. Washing was performed with hot water until the cooked mass was free from spent liquor. After thorough washing, the unscreened pulp yield was calculated and the pulp was screened on a Serla laboratory screen, using a $0.25 \mathrm{~mm}$ slot width mesh.

\section{Pulp characteristics}

Unbleached pulp characteristics, such as unbleached pulp yield, kappa number (Tappi T: 236 OM 99), brightness (ISO 2470) and intrinsic viscosity (Scan C15:62), were analyzed.

\section{Bleaching}

Conventional and ECF bleaching sequences, i.e. $\mathrm{CEpH}_{1} \mathrm{H}_{2}$ and DEpD, were performed using optimized bleaching conditions to get final bleached pulp brightness of $85 \%$ (ISO).

\section{Physical strength properties}

The bleached pulp of Kans grass was beaten in a Laboratory PFI mill at 0 and 500 revolutions. Laboratory-made handsheets were prepared using a laboratory British Sheet Former. After that, the bleached pulp sheets were pressed in a lab press and stored for 24 hours under atmospheric conditions for drying. Further, the dry bleached pulp sheets were 
conditioned at a temperature of $27 \pm 1{ }^{\circ} \mathrm{C}$ and relative humidity of $65 \pm 1 \%$ before determining the physical strength properties. The bleached pulp sheets were then evaluated with regard to their physical strength properties.

The following ISO and Tappi standard test methods were used for pulp and handsheet evaluation: freeness
(mL CSF), ISO-5267/2; pulp refining (PFI mill), ISO5264; handsheet preparation, ISO-5269/1; burst index, ISO-2758; tear strength, ISO-1974; tensile index, ISO1924; folding endurance, ISO-DIS-5626, and porosity, T-547-pm-88.

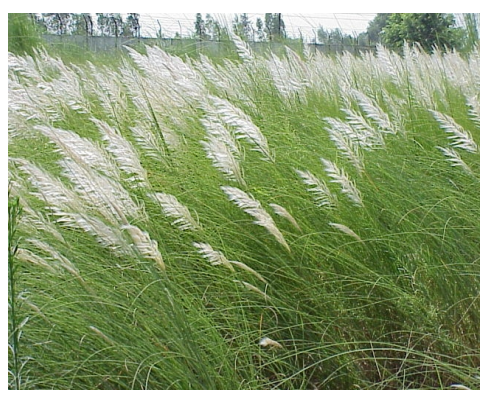

Figure 1: Kans grass in the field

Table 1

Comparison of chemical composition of Kans grass with that of bamboo and bagasse

\begin{tabular}{lcccc}
\hline Parameters & Unit & Kans grass & Bamboo & Bagasse \\
\hline Ash content & $\%$ & 6.76 & 2.7 & 1.7 \\
Cold water solubility & $\%$ & 12.61 & 4.0 & 1.3 \\
Hot water solubility & $\%$ & 15.46 & 4.8 & 2.8 \\
1/10 N NaOH solubility & $\%$ & 42.23 & 25.1 & 25.8 \\
Alcohol benzene solubility & $\%$ & 4.01 & 2.6 & 2.5 \\
Pentosans & $\%$ & 15.9 & 16.5 & 25.5 \\
Holocellulose & $\%$ & 69.2 & 73.2 & 71.3 \\
Alpha-cellulose & $\%$ & 33.21 & 44.9 & - \\
Beta-cellulose & $\%$ & 23.55 & 19.7 & - \\
Gamma-cellulose & $\%$ & 12.43 & 8.6 & - \\
Acid insoluble lignin & $\%$ & 22.43 & 23.4 & 24.9 \\
Acid soluble lignin & $\%$ & 1.60 & 0.5 & - \\
\hline
\end{tabular}

\section{RESULTS AND DISCUSSION}

\section{Chemical proximate analysis of Kans grass}

The results of chemical proximate analysis of Kans grass, compared with those for bagasse and bamboo, are presented in Table 1. The main chemical components of Kans grass are holocellulose (69.2\%), lignin (22.4\%), 6.8\% inorganic salt and $4.01 \%$ alcohol-benzene. The ash content, cold water, hot water, $0.1 \mathrm{~N} \mathrm{NaOH}$ solubility and alcohol-benzene solubility are higher in Kans grass, compared to the same parameters for bagasse and bamboo. ${ }^{6}$ However, the holocellulose content is lower in Kans grass than in bamboo and bagasse. ${ }^{7}$ Overall, the composition of Kans grass is similar to that of agro-residues and therefore it has substantial potential for production of quality pulp for various grades of paper.

\section{Morphology of Kans grass}

The results listed in Tables 2 and 3 reveal that, morphologically, the type of cell arrangement in Kans grass fiber is almost similar to that in Sarkanda and Sabai grasses. The fibers are mostly regular in size, long and slender, with sharp ends. The length of Kans grass fiber varies from 0.20 to $3.90 \mathrm{~mm}$, with an average fiber length of 1.40 $\mathrm{mm}$. The average fiber diameter of Kans grass is $15.4 \mu \mathrm{m}$. The fiber diameter and wall thickness of Kans grass govern fiber flexibility and elasticity. The Runkel ratio of Kans grass is 1.31. Fibers considered as thick-walled are stiffer, less flexible and form bulky paper sheets with lower bonded area. ${ }^{8}$ Parenchyma cells are numerous, from small to large, rectangular to rounded, somewhat larger than in other grasses, and their length varies from 


\section{ARVIND KUMAR SHARMA et al.}

22.0 to 312 microns (average of $91 \mu \mathrm{m}$ ) and 12 to $98 \mu \mathrm{m}$ (average of $35 \mu \mathrm{m}$ ) in width. Vessels vary from very short to long, from $104 \mu \mathrm{m}$ to $1265 \mu \mathrm{m}$ (average of $489 \mu \mathrm{m}$ ) and width varies from $25 \mu \mathrm{m}$ to $92 \mu \mathrm{m}$ (average of $38 \mu \mathrm{m}$. Epidermal cells are tapered and cylindrical with toothed margins. The length of epidermal cells varies from 57 to 163 $\mu \mathrm{m}$ (average of $81 \mu \mathrm{m}$ ) and width from 8 to 16.3 $\mu \mathrm{m}$ (average of $13.5 \mu \mathrm{m}$ ). ${ }^{9}$

The plots for fiber length distribution and fiber width distribution for Kans grass fiber are based on the data generated by the Fiber Quality Analyzer, and presented in Figures 3 and 4.

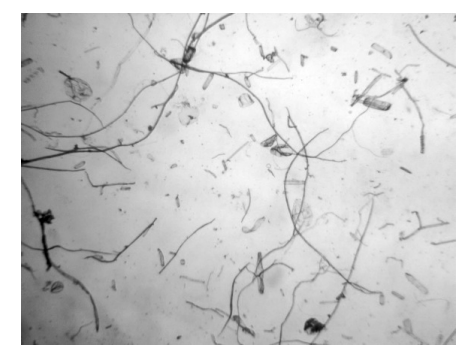

Figure 2: Microscopic view of Kans grass fiber

Table 2

Fiber characteristics of Kans grass pulp

\begin{tabular}{lcc}
\hline Dimensions & Unit & Kans grass pulp \\
\hline $\begin{array}{l}\text { Mean fiber length (weight weighted) } \\
(\mathrm{L}=0.20-5.0 \mathrm{~mm})\end{array}$ & $\mathrm{mm}$ & 1.398 \\
$\begin{array}{l}\text { Mean fiber width } \\
(\mu=7-35)\end{array}$ & $\mu \mathrm{m}$ & 15.4 \\
$\begin{array}{l}\text { Fiber curl index (weight weighted) } \\
(\mathrm{L}=0.50-5.0 \mathrm{~mm})\end{array}$ & - & 0.135 \\
Fiber kink index & & \\
$(\mathrm{L}=0.50-5.0 \mathrm{~mm})$ & & \\
Kink index & $(1 / \mathrm{mm})$ & 1.93 \\
Total kink angle & degrees & 35.90 \\
Kinks per mm & $(1 / \mathrm{mm})$ & 0.93 \\
Fines & & \\
$(\mathrm{L}=0.01-0.20 \mathrm{~mm})$ & & \\
Arithmetic & $\%$ & 55.71 \\
Length weighted & $\%$ & 13.59 \\
\hline
\end{tabular}

Table 3

Fiber dimensions of unbleached Kans grass soda pulp determined by the projection microscope

\begin{tabular}{lcc}
\hline Particulars & Units & Results \\
\hline Lumen diameter & $\mu \mathrm{m}$ & 6.64 \\
Fiber wall thickness & $\mu \mathrm{m}$ & 4.38 \\
Runkel ratio & - & 1.31 \\
Parenchyma length & $\mu \mathrm{m}$ & 91.1 \\
Parenchyma diameter & $\mu \mathrm{m}$ & 35.0 \\
Vessel length & $\mu \mathrm{m}$ & 489.0 \\
Vessel diameter & $\mu \mathrm{m}$ & 38.0 \\
\hline
\end{tabular}




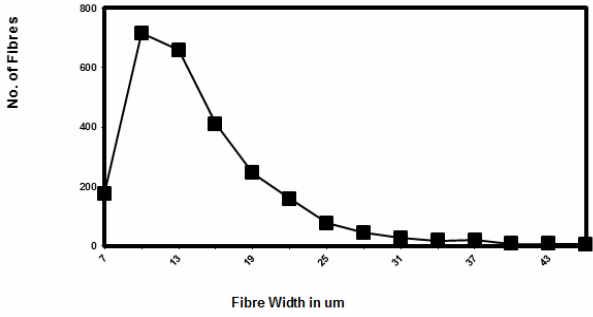

Figure 3: Frequency distribution graph of fiber width $v s$ number of fibers

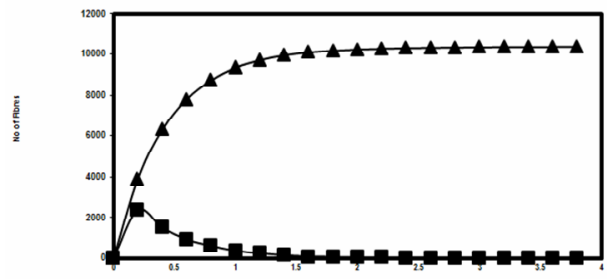

Lenght (mm)

Figure 4: Frequency distribution graph of fiber length $v s$ number of fibers

Table 4

Optimization of soda pulping of Kans grass

\begin{tabular}{lcccc}
\hline Parameters & Unit & Exp. 1 & Exp. 2 & Exp. 3 \\
\hline Alkali charge, \% $(\mathrm{NaOH})$ & $\%$ & 14 & 16 & 18 \\
Bath ratio & - & $1: 5$ & $1: 5$ & $1: 5$ \\
Unscreened pulp yield & $\%$ & 47.0 & 45.5 & 42.5 \\
Rejects content & $\%$ & 0.87 & 0.40 & nil \\
Screened pulp yield & $\%$ & 46.13 & 45.1 & 42.5 \\
Pulp kappa number & - & 20.9 & 17.7 & 15.0 \\
Unbleached pulp brightness & $\%(\mathrm{ISO})$ & 23.9 & 26.1 & 27.9 \\
Pulp viscosity & $\mathrm{cm}^{3} / \mathrm{g}$ & 686 & 616 & 587 \\
\hline Constant cooking conditions & & & & \\
\hline Raw material $(0 . \mathrm{d})$. & $\mathrm{g}$ & 200 & 200 & 200 \\
Material to liquor ratio & & $1: 5$ & $1: 5$ & $1: 5$ \\
\hline Cooking schedule & $\mathrm{min}$ & & \\
\hline Ambient to $100{ }^{\circ} \mathrm{C}$ & $\mathrm{min}$ & 100 & 30 & 30 \\
$100{ }^{\circ} \mathrm{C}$ to $165{ }^{\circ} \mathrm{C}$ & $\mathrm{min}$ & 120 & 100 & 100 \\
At cooking temp. $165^{\circ} \mathrm{C}$ & & & & 120 \\
\hline
\end{tabular}

\section{Soda pulping of Kans grass}

Table 4 reveals the effect of alkali doses on the screened pulp yield and kappa number under the cooking conditions. The screened pulp yield and kappa number decrease with increasing alkali dose from 14 to $18 \% \mathrm{NaOH}$, thus, at the alkali dose of $18 \% \mathrm{NaOH}$, the screened pulp yield dropped to $42.5 \%$ (a decrease of $7.86 \%$, compared to the screened pulp yield of $46.13 \%$ obtained at the lowest alkali dose), while kappa number is reduced by 5.9 units. At higher alkali dose, the degradation of carbohydrates occurs very fast because of peeling reactions. ${ }^{10}$ Therefore, the optimum alkali dose of $16 \%$ $\mathrm{NaOH}$, bath ratio of 1:5 and total cooking time of 4.1 hours were selected as optimum pulping conditions. The Kans grass sample obtained under these conditions (unbleached pulp with a kappa number of 17.7 and unscreened pulp yield of
45.5\%) was further evaluated with regard to its paper-making potential.

\section{Bleaching of unbleached soda pulp of Kans grass}

The unbleached soda pulp of Kans grass was bleached using conventional $\mathrm{CEpH}_{1} \mathrm{H}_{2}$ and DEpD bleaching sequences to obtain pulp brightness of 83 to $86 \%$ (ISO). Table 5 reveals that the DEpD sequence yielded bleached pulp brightness, which is 2.4 units higher than that obtained by the $\mathrm{CEpH}_{1} \mathrm{H}_{2}$ sequence. The final pulp viscosity is $16 \%$ higher in the case of DEpD bleached soda pulp, compared to that bleached by the $\mathrm{CEpH}_{1} \mathrm{H}_{2}$ sequence. The post-color number of the $\mathrm{CEpH}_{1} \mathrm{H}_{2}$ sequence bleached pulp is $62.7 \%$ higher than that of ECF bleached pulp. It means that brightness reversal will be higher in the case of $\mathrm{CEpH}_{1} \mathrm{H}_{2}$ bleached pulp, compared to that bleached by DEpD. 
Table 5

Bleaching of Kans grass soda pulp by $\mathrm{CEpH}_{1} \mathrm{H}_{2}$ and DEpD sequences, as well as by conventional and ECF sequences

\begin{tabular}{|c|c|c|c|c|c|c|}
\hline Parameters & & & & $\mathrm{CEpH}_{1} \mathrm{H}_{2}$ & & \\
\hline Kappa number & & & & 17.7 & & \\
\hline C Stage $/ \mathrm{D}_{0}$ Stage & & & & & & \\
\hline $\mathrm{Cl}_{2}$ added as (\% avai & chlorine) & & & 4.42 & & \\
\hline Residual chlorine, $\mathrm{p}$ & & & & 87 & & \\
\hline Ep stage & & & & & & \\
\hline $\mathrm{NaOH}$, added & & & & 2.0 & & \\
\hline Hypo $\left(\mathrm{H}_{1}\right)$ stage $/ \mathrm{D}_{1}$ & & & & & & \\
\hline Calcium hypochlorit & $\mathrm{d}$ as $(\%$ a & ilable chlc & & 1.5 & & \\
\hline Residual $\mathrm{Cl}_{2}$, ppm & & & & 52 & & \\
\hline Hypo $\left(\mathrm{H}_{2}\right)$ stage & & & & & & \\
\hline Calcium hypochlorit & ed as $(\%$ a & ilable chlc & & 1.0 & & \\
\hline Residual $\mathrm{Cl}_{2}$, ppm & & & & nil & & \\
\hline Final pulp brightness & SO) & & & 83.4 & & \\
\hline Final bleached pulp & ity, $\mathrm{cm}^{3} / \mathrm{g}$ & & & 379 & & \\
\hline $\mathrm{PC}$ number & & & & 1.1 & & \\
\hline Bleaching conditions & Iventional & d ECF se & ice) & & & \\
\hline Parameter & $\mathrm{Cl}_{2}$ & $\mathrm{D}_{0}$ & Ep & $\mathrm{H}_{1}$ & $\mathrm{H}_{2}$ & $\mathrm{D}_{1}$ \\
\hline $\mathrm{pH}$ & $<2$ & $2.5 \pm 0.2$ & 11.0 & 10.5 & 10.5 & $3-4$ \\
\hline Pulp consistency, $\%$ & 3.0 & 5.0 & 10 & 10 & 10 & 10 \\
\hline Temperature, $\left({ }^{\circ} \mathrm{C}\right)$ & ambient & $45 \pm 5$ & $65 \pm 5$ & $45 \pm 5$ & $45 \pm 5$ & $80 \pm 5$ \\
\hline Retention time, min & 40 & 50 & 60 & 120 & 120 & 180 \\
\hline
\end{tabular}

Table 6

Physical strength properties of Kans grass pulp bleached by $\mathrm{CEpH}_{1} \mathrm{H}_{2}$ and DEpD sequences

\begin{tabular}{lccccc}
\hline Properties & Units & $\mathrm{CEpH}_{1} \mathrm{H}_{2}$ bleached pulp & \multicolumn{2}{c}{ DEpD bleached pulp } \\
\hline PFI & $\mathrm{rev}$ & 0 & 500 & 0 & 500 \\
Freeness & $\mathrm{mL} \mathrm{CSF}$ & 360 & 285 & 400 & 321 \\
Apparent density & $\mathrm{g} / \mathrm{cm}^{3}$ & 0.78 & 0.83 & 0.81 & 0.83 \\
Burst index & $\mathrm{kPa} \mathrm{m}^{2} / \mathrm{g}$ & 3.35 & 4.30 & 3.87 & 4.96 \\
Tensile index & $\mathrm{Nm} / \mathrm{g}$ & 50.0 & 55.0 & 56.0 & 62.0 \\
Tear index & $\mathrm{mNm} / \mathrm{g}$ & 6.50 & 5.20 & 6.80 & 6.20 \\
Fold Kohler & $\log$ & 1.78 & 1.98 & 1.89 & 2.1 \\
Porosity & $\mathrm{mL} / \mathrm{min}$ & 340 & 130 & 440 & 180 \\
Zero span tensile strength & $\mathrm{km}$ & 9.1 & - & 9.5 & - \\
\hline
\end{tabular}

\section{Physical strength properties}

Table 6 shows a comparison with regard to physical strength properties of $\mathrm{CEpH}_{1} \mathrm{H}_{2}$ and DEpD bleached soda pulps of Kans grass, unbeaten and beaten at a beating level of $350 \mathrm{~mL}$ CSF at 500 rev. The DEpD bleached soda pulp showed an improvement in tear index (16.1\%), burst index (13.3\%) and tensile index (11.3\%), compared to the corresponding properties of the $\mathrm{CEpH}_{1} \mathrm{H}_{2}$ bleached pulp. In spite of being a soda pulp, the physical strength properties of the Kans grass bleached pulp are good. ${ }^{11}$ The zero-span tensile strength of the unbeaten DEpD and $\mathrm{CEpH}_{1} \mathrm{H}_{2}$ bleached soda pulp of Kans grass is 9.5 $\mathrm{km}$ and $9.1 \mathrm{~km}$, respectively.

The Bauer McNett classification of the Kans grass bleached soda pulp illustrated in Table 7 reveals that the total useful fiber fraction $(+30$ and +50 fraction) of Kans grass pulp is of $30 \%$, which is good for the physical strength properties of the pulp. However, the pulp has a high proportion of primary fines, as indicated by passing the 200 mess size, i.e. $39.3 \%$, which causes drainage problems. 
Kans grass

Table 7

Bauer McNett classification of bleached Kans grass pulp

\begin{tabular}{lc}
\hline $\begin{array}{l}\text { Fiber fraction retained on } \\
\text { mesh size }\end{array}$ & Percentage \\
\hline+30 & 20.5 \\
+50 & 10.8 \\
+100 & 24.4 \\
+200 & 5.0 \\
Passing 200 & 39.3 \\
\hline
\end{tabular}

\section{CONCLUSION}

The Kans grass has about 30\% long fiber fraction, coupled with good zero-span tensile strength. However, it contains a high proportion of primary fines, which causes slow drainage during paper-making. The pulp and paper-making quality of Kans grass pulp is comparable to those of wheat straw and bagasse pulps. Therefore, it can be concluded that good quality writing and printing papers can be produced using Kans grass pulp. Also, using modern bleaching sequences, it is possible to achieve more than $85 \%$ (ISO) brightness for Kans grass pulp.

ACKNOWLEDGEMENT: The authors wish to thank Dr. Sanjay Tyagi, Scientist E-I for helping in pulp evaluation studies. The project activities were supported by the Development Council (DIPP), New Delhi, India.

\section{REFERENCES}

1 A. K. Sharma, D. Dutt, J. S. Upadhyaya and T. K. Roy, Bioresources, 6, $5062 \quad$ (2011), https://bioresources.cnr.ncsu.edu/BioRes_06/BioRes_0 6_4_5062_Sharma_DUR_Anatom_Morph_Chem_Ba musa_Eucalyptus_2140.pdf

2 The Wealth of India: Raw Materials Publication and Information Directorate, CSIR, New Delhi, India, 1951 ,

https://www.niscair.res.in/ActivitiesandServices/Produ cts/Woi1.html

3 S. V. Subrahmanyam, R. Godiyal, V. Janbade and A. Sharma, "Preparation of monograph of different fibrous raw materials used by Indian paper industry", 2004, Central Pulp and Paper Research Institute, Saharanpur, India, http://www.dcpulppaper.org/gifs/ report24.pdf

S. R. D. Guha and R. Pant, "Papermaking Fibers", Dehradun, Shiva Offset Press, 1988

5 S. R. D. Guha and R. Pant, Indian Journal of Forestry, 257, 24 (1963)

6 S. V. Subrahamanyam, A. K. Sharma, R. D. Godiyal, V. T. Janabade and H. K. Gupta, IPPTA Convention Issue, 2001, pp. 31-35, https://www.ippta.co/eLibraryNew/2001/IPPTA\%20(C
I\%202001)\%2031\%20\%2035\%20Effect\%20of\%20Kappa.pdf

7 S. R. D. Guha, G. M. Mathur and Y. K. Sharma, Indian Forester, 93, $19 \quad$ (1967), http://www.indianforester.co.in/index.php/indianforest er/article/view/25516

${ }^{8}$ M. K. Islam and M. S. Jahan, IPPTA J., 13, 7 (2001),

https://www.ippta.co/eLibraryNew/2001/IPPTA\%2013 (2)\%207\%20-

\%2012\%20Blending\%20of\%20Nonwood.pdf

9 S. R. D. Guha, G. M. Mathur and Y. K. Sharma, Indian Forester, 92, $184 \quad$ (1966), http://www.indianforester.co.in/index.php/indianforest er/article/view/25325

10 G. G. Bhargava and R. P. Dwidevi, IPPTA J., 18, 19

$(1981)$

https://www.ippta.co/eLibraryNew/1981/IPPTA\%20X VIII(3)\%2019\%20-

$\% 2025 \% 20$ Gmelina\%20Arborea\%20(Gamari).pdf

11 M. Sarwar Jahan, M. Khalidul Islam, A. J. M. Moynul Hasa and D. A. Nasima Chowdhury, TAPPSA J., May, $\quad 21 \quad$ (2002) www.tappsa.co.za/archive/Journal_papers/Investigatio n_on_soda/investigation_on_soda.html 